\title{
Václav Havel: Building Beyond Democracy
}

James F. Lea, University of Southern Mississippi

Edward M. Wheat, University of Southern Mississippi

This study explicates the political thought of the playwright and dissident Václav Havel, who emerged as the most important and visible central European intellectual during the ferment leading up to the revolutions of 1989 and now serves as President of Czechoslovakia. Havel's political thought is centered in the interaction of three themes: the idea of a pretheoretical anti-politics from below; the phenomenon of the second, or parallel, culture; and the principle of living in truth. His ideas are likely to have great impact on Czechoslovakia and possibly other central and east European nations undertaking democratization.

It is commonly believed that Czechoslovakia has the best chance at building democracy of any of those central European countries whose citizens cast off their Stalinist regimes in 1989. This is so for a number of reasons. Czechoslovakia has a notable democratic tradition stretching all the way back to the nation's origin in 1918. Playing a key role in this was philosopher and devoted democrat Jan Masaryk, who helped found and lead the new nation. Also, Czechoslovakia was the only central European country that did not become fascist in the 1940s and was the last country to fall under one-party Communist rule at the end of that decade. It has a sound industrial base (at least in the Czech region), and can draw on remarkably vital literary and folk cultures (Roskin 1991; Ash 1991). Perhaps that is why Czechoslovakia produced the most important and visible intellectual to give voice to the aspirations of central Europeans in the 1970s and 1980s, the highly respected playwright and courageous dissident Václav Havel.

Havel endured several jailings and a brutal prison term in the 1980s, prior to assuming the presidency of the country on December 29, 1989. In his years of political struggle, in his plays and essays, and in his role as president Havel has persistently pursued one constant goal -- to develop in his country what is best called a "post-democratic politics from below." That is, he is not interested only in building the formal rules, institutions, processes, etc., of western democracy, but in augmenting these with a certain way of living in the broader Czech culture. Thus, Havel refers to western style democracy as only a "transitional solution" for his nation $(1985,91)$.

Without question, one reason Havel does not accept democracy as the final solution is due to the fact that the democratic nations let his people down repeatedly in the twentieth century. At the Munich Conference in 1938 Britain and France conceded Hitler's annexation of the Sudetenland, opening the door to German takeover of Czechoslovakia. In 1948 when the Marxists engineered a coup, probably murdering Jan Masaryk's son, Thomas, the west did nothing. Again in 1968, when the Soviets sent in a half-million soldiers and five thousand 
assault vehicles, the west stood idly by. Soon thereafter, under Nixon's leadership the west pursued a policy of detente with the Brezhnev regime that had ordered the invasion. Finally, various elements of the western anti-nuclear and peace movements spoke softly about the repression of dissidence in Russia and central Europe to protect their narrow political agendas (Havel 1989b, 164-165).

\section{Havel's Life and Work}

Although an international public now knows Havel from his leadership of Civic Forum and as President of Czechoslovakia, it is almost certain that, other than students of theater and the dissident community of central Europe, few people have read his works. Insight into the ideational background of Havel's political thought is available in the dozens of plays he has written over the past thirty years. These range from one-act plays such as "Audience" to his best known work, "The Memorandum" (in 1965), and have been produced hundreds of times and have reaped numerous awards in the West. The "motif of loss of self" (Havel 1990a, 196) is central to Havel's dramatic works, although the plays are not overly didactic.

My ambition is not to soothe the viewer with a merciful lie or cheer him up with a false offer to sort things out for him .... I'm trying to ... propel him, in the most drastic possible way into the depths of a question he should not, and cannot, avoid asking .... The only ways out, the only solutions, the only hopes that are worth any thing are the ones we discover ourselves, within ourselves, and for ourselves (1990a, 199).

Thus Havel seeks to provoke theater audiences to an authentic recognition of the multiple threats to self and identity in our time.

There are numerous other works, from radio scripts and commentaries to major addresses in Czechoslovakia and abroad (Havel 1990b; Rosen 1990; Felton 1990), that have drawn attention to the thought of Havel. The most important of his works for political theory, however, are his intellectual autobiography, Disturbing the Peace (1990a), and the six post-invasion essays penned after 1968. They are the bases for the discussion of Havel's thought that follows.

Disturbing the Peace was self-published in 1986 (customary in the underground culture of that time), appeared in Germany the following year, and came out in the United States in 1990. Written in the form of essays respondent to fifty questions put to Havel by an exiled friend in Germany, the book covers Havel's coming of age in a bourgeois family just after the 1948 coup, and his subsequent struggle throughout the 1950s to get the education denied to youth of his class under the Communist regime. It recounts his entry into the theater, the years of liberalization, and the personal, political, and cultural devastation of 1968 . It details the harrowing years that followed (the years of normalization, in the 
parlance of the regime), with their omnipresent surveillance, numerous arrests, interrogations, show trials, dissident organizations such as Charter ' 77 and the Committee for the Defence of the Unjustly Prosecuted, Havel's prison terms at hard labor, and the persistence of his hopes and dreams for Czechoslovakia.

Also important are the half-dozen post-invasion essays, beginning with "On the Subject of Opposition" in 1968 and concluding with "Politics and Conscience" in 1984. Without question the most important of these is "The Power of the Powerless," written in 1978. Warsaw Solidarity leader Zbygniew Bujak commented in 1981 that this essay "gave us theoretical backing, a theoretical basis for our actions. He enabled us to believe in their effectiveness. Until I read his text I was full of doubts" (Lukes 1985, 12). However, these lengthy, often complex essays do not in any sense comprise a rigorous philosophy or systematic political theory. Nor did Havel ever aspire for these works to be taken as such. He admits in Disturbing the Peace that he often deliberately invented concepts such as "the post-totalitarian system" for use in one essay or another, and then never used them again. He refers to these as "situational linguistic aids" (Havel 1990a, 9).

\section{Havel's Political Thought}

The favorite comparison for the revolutions in central Europe in 1989 continues to be the revolution in France of two centuries before, and that is a useful angle from which to enter Havel's political thought -- especially in regard to his notion of a post-democratic society. It is commonly accepted that the French revolutionaries of 1789 were strongly influenced by the theoretical formulations of a stylish, self-educated literary figure and controversial thinker who was often to be found in avant-garde Parisian salons, and who often found himself at odds with the Bourbon regime. This was, of course, Jean-Jacques Rousseau, called the mentor of the French revolution by Simon Schama (1989). There are fascinating parallels between the role of these two men in their respective revolutions. Just as Rousseau's works were widely read in pre-revolutionary France, so Havel's plays and post-invasion essays were widely circulated in the underground or "second culture" of pre-revolutionary Czechoslovakia. And just as Rousseau's Social Contract was printed in the early 1790s in pocket bible size for wide distribution (O'Brien 1988, 62-72), so Disturbing the Peace was the first underground work to be published after the beginning of the revolutions in central and eastern Europe. Both men were largely self-taught, and each became one of the most highly visible intellectuals and literary figures of his generation. Their first love was not political theory, but both felt compelled to speak to politics, and they both saw themselves as speaking for a community of sufferers, a "community of the shaken," as Havel phrases it (1989c, 157). They even presented themselves in similar ways, as radical nonconformists -- hippies, if you will -- who drew ideas directly from their own lived experience rather than imposing ideas on it.

But there is a difference between the two, and it is a huge one for political 
thought. Rousseau was one of those many Enlightenment figures who went beyond opposition and criticism to an abstract vision, what he called the sacred and sovereign General Will, and he prescribed a means of achieving it, the ironclad unanimous social contract binding a national population. He claimed this solution to be "underwritten by reason" (Rousseau 1954, 14).

It is precisely this modern conceit -- of ideologically reifying disembodied concepts and rationalistic methodologies of power -- that Havel, like many others, condemns as leading to the impersonal, almost global automatism of the late twentieth century. He notes in his essay "Thriller" that a fundamental weakness of Western civilization is that it "recognizes only such thinking in concepts" (Havel 1989e, 159). Various formalistic political models or privileged political concepts or abstractions such as Rousseau's social-contract democracy are critiqued by Havel. Among those he has explicitly attacked are technical reason, Marxism, utilitarianism, bureaucratic hierarchy, and capitalism. They are all justified by "Reason," and they lie -- to borrow a phrase from Jefferson -- like the dead hand of past generations on the living. In "Politics and Conscience," he writes that these privileged concepts "are new, man-made absolute(s), devoid of mystery, free of the "whims' of subjectivity and, as such, impersonal and inhuman" (Havel 1989c, 138). These notions, once institutionalized, "petrify thought in a hermetic structure of static concepts," and enclose, restrict, repress, squeeze the life from the living (Havel 1990a, 9). It is the power of this conceptual baggage from the past, as carried by centralized political control structures, that Havel challenges.

Indeed, he suggests this is the ground of a "single, common crisis" of west and east, of both consumer and Marxist societies (Havel 1990a, 10). It is a crisis most easily seen in the latter, however, "on [whose] exposed rampart ... the wind blows most sharply" (Havel 1989c, 156). Havel asks, "Do we not in fact stand ... as a kind of warning to the West, revealing to it its own latent tendencies?" (Havel 1985, 38-39). In a penetrating passage, he explains further:

It would appear that the traditional parliamentary democracies can offer no fundamental opposition to the automatism of technological civilization and the industrial-consumer society, for they, too, are being dragged helplessly along by it. People are manipulated in ways that are infinitely more subtle and refined than the brutal methods used in the post-totalitarian societies. But this static complex of rigid, conceptually sloppy and politically pragmatic mass political parties run by professional apparatuses and releasing the citizen from all forms of concrete and personal responsibility; and those complex foci of capital accumulation engaged in secret manipulations and expansion; the omnipresent dictatorship of consumption, production, advertising, commerce, consumer culture, and all that flood of information: all of it, so often analysed and described, can only with great difficulty be imagined as the source of humanity's rediscovery of itself (Havel 1985, 91). 
In the west, as in the east under Marxism, there is mere ritualistic political participation, but the reified concepts of social contract theory obscure a fuller understanding, much as does the manipulation of masses by professional communications consultants using powerful information technologies. In the west, as in the east, macroeconomics, not life, has priority, and power is held at the top, but the sacred concepts of capitalist democracy block comprehension and critique. In the west, as in the east, there is a hegemony of centralized, regime culture, but the notions of pluralism and the marketplace of ideas put a different face on it. In both east and west, citizenship atrophies, personal responsibility is either denied or abandoned, and even self-identity and the grasp of personal values jeopardized.

A person who has been seduced by the consumer value system, whose identity is dissolved in an amalgam of the accoutrements of mass civilization, and who has no roots in the order of being, no sense of responsibility for anything higher than his or her own personal survival, is a demoralized person. The system depends on this demoralization, deepens it, is in fact a projection of it into society (Havel 1985, 45).

Havel thinks his countrymen have developed, through struggle (especially since the 1968 Soviet invasion), a better base for the polis. It is a way different not only from the self-directing, auto-pilot post-totalitarianism of central Europe, but also from the ritualistic consumer democracies of the west. Though Havel is at pains to avoid "binding categories" and often uses "situational linguistic aids" that he later discards, there are three fairly clear ideas that emerge from all of his works: 1) a persistently pretheoretical anti-political stance; 2) the ground of an independent culture; and, 3) living in truth. These may lead, Havel believes, to a new kind of "politics from below" and a post-democratic polis, although there are no money-back guarantees.

\section{Anti-Politics From Below}

Turning to the first of these, Havel sees Czechoslovakians' skepticism not only of the Stalinist regime but also of "alternative political models and programs" as "a bit of healthy social instinct" (Havel 1985, 51). To him, this skepticism signifies a rejection of "politics growing ... from a thesis," which is the spirit and method of traditional politics (Havel 1989c, 157). He believes his people have learned through bitter experience to reject all generalizations and intellectual stereotypes.

We are now better equipped than ever before to see the human world as it really is: a complex community of thousands of millions of unique, individual human beings, in whom hundreds of beautiful characteristics are matched by hundreds of faults and negative tendencies. They must never be lumped together into homogeneous masses beneath a welter of hollow cliches and sterile words 
and then en bloc -- as "classes," "nations," or "political forces" -- extolled or denounced, loved or hated, maligned or glorified (Havel 1989a, 29).

This new anti-ideological spirit transcends the battle over political schemes, a battle "from another world and another time" (Havel 1985, 72). The west, in Havel's view, understands little of this, "little of what is actually at stake" (Havel 1989c, 150; see also Kohak 1990). They still tend to see it as a battle over models, especially capitalism and socialism, whereas in truth, such "semantically confused categories have long since been beside the point" (Havel 1989c, 149). The key is not a free market, a written constitution, or a two-party system. Havel argues a position far more profound than merely returning to the everyday mechanisms of Western democracy, since these embody only another, if more benign, variant of the reduction of politics "to a mere technology of rule and manipulation"(Havel 1989c, 143). "I favour 'anti-political politics," "Havel says, "that is politics ... not as cybernetic rule over humans or as the art of the useful, but politics as one of the ways of seeking and achieving meaningful lives .... politics from below. Politics of man, not of the apparatus," nor of the concept, the thesis, the program, the fixed vision, the established processes, the tradition (Havel 1989 c, 155, 157).

Is it possible, this politics from below, open and free of the enclosing restrictions of abstractions? Is it viable as a strategy of achieving meaningful lives? Havel professes to have learned in prison that everything is possible. But the viability of this post-democratic potential turns very much, in his estimation, on the presence of independent culture, such as was developed by himself and so many others in the period of "normalization," for which effort thousands were imprisoned.

\section{Independent Culture}

A recent article on civil versus political freedoms in The Atlantic captures Havel's point about culture very concisely. The author said, "governments appear to respond to the popular will as expressed through the communications media, demonstrations, and other informal channels with more alacrity than they do to the often indeterminate results at the polling station" (Gastil 1990,93). Havel would agree with this estimation of the power of informal channels over ballots. Thus he concludes that one must live in the broader culture, at all costs, as if one were free. As he argued in "Six Asides About Culture:" "The counterpart of power in this conflict is not an alternative political idea but the autonomous, free humanity of man and with it also art -- precisely as art! -- as one of the most important expressions of this autonomous humanity" (Havel 1989d, 133). He believes this is proven in Czechoslovakia, as illustrated by the different outcomes in 1968 and 1989. In the former instance when the population was so effectively subdued, novelist Milan Kundera talked of a "Biafra of the spirit" (Havel 1989d, 
124). But Havel saw deeper, saw an "irrepressible cultural hunger" which would sustain a better politics once it achieved full development in a "parallel culture" (Havel 1989d, 123, 127). From the mid-1970s on, as thousands began to live as if they were free, the parallel culture, or second culture, flourished in "hundreds of underground volumes, tens of typewritten magazines, private or semi-official exhibitions, seminars, concerts and other events ... small theaters crammed full of people ... queues at book stores ... young people travelling half way across the country to attend a concert that may not take place at all" (Havel 1989d, 125).

The idea of a vigorous and lively parallel culture is central to Havel's thought. He contends that such a culture "sets our drowsy souls and our lazy hearts "moving," "and suggests that this can not be separated from "an awakening human community" (Havel 1989d, 135). Thus, from 1956, when it all began for him at the first rock concert in Czechoslovakia, through the world of the theater in the 1960s and the movement in defense of the rock group "The Plastic People of the Universe" in 1976, to the present, in which his advisors include a playwright, a rock musician, a geographer, an actress, a painter, and a scriptwriter, culture is everything to Havel. It is the ground of the pretheoretical politics from below.

\section{Living in Truth}

Havel draws heavily on the emphasis of European existentialists on authenticity for his notion of living in truth. He formulated this idea in response to the situation of central Europeans having to "live within the lie" of the regime (Havel 1985,35). Havel presented the internal dimension of this phenomenon with the metaphor of the bathroom in his essay on "Politics and Conscience" (1989c, 142), and illustrated the external dimensions with the greengrocer parable in his essay on "The Power of the Powerless" $(1985,27 \mathrm{ff})$. Neither trope is complex, but both are compelling and speak to the felt experience of humans behind the many types of "Iron Curtains" about the world.

The bathroom metaphor is intended to portray the immense privatization of life and attendant withdrawal from the public world under advanced totalitarianism. Citizens lock away in their most inaccessible place their true ideas, feelings, judgements, values, perspectives, and hopes, closing and locking the door as when entering a bathroom, allowing no one to enter. Havel argues that the extent of this privatization is what misled Milan Kundera, and virtually all western observers and Communist regime elites, to see only apathy, indifference, passivity, and a supposed death of the spirit in the peoples of central and eastern Europe.

Havel is notorious for reminding his fellow citizens that totalitarianism cannot be blamed simply on elites but is within everyone, carried out daily by everyone. The greengrocer parable portrays the immense outward conformity to the prescribed rituals of the regime and was widely read and discussed in central Europe in the time leading up to the revolutions of 1989. The greengrocer is everyman, each day putting beside the vegetables in his shop window the expected 
signs espousing regime slogans. Havel suggests that nothing will change until, one day, a person opens the bathroom door and reveals his or her thoughts to others, or the greengrocer changes his signs.

Let us now imagine that one day something in our greengrocer snaps and he stops putting up the slogans merely to ingratiate himself. He stops voting in elections he knows are a farce. He begins to say what he really thinks at political meetings. And he even finds the strength ... to express solidarity with those whom his conscience commands him to support. In this revolt the green grocer steps out of living within the lie. He rejects the ritual and breaks the rules of the game. He discovers once more his suppressed identity and dignity. He gives his freedom a concrete significance. His revolt is an attempt to live within the truth (Havel 1985, 39).

Why people begin to live within the truth is inexplicable, but Havel is convinced they are inclined to do so.

Society is a very mysterious animal with many faces and hidden potentialities, and ... it's extremely shortsighted to believe that the face society happens to be presenting to you at a given moment is its only true face. None of us know all the potentialities that slumber in the spirit of the population, or all the ways in which that population can surprise us when there is the right interplay of events, both visible and invisible (Havel 1990a, 109).

One finds in Havel's writings many examples of living within the truth. They range from self-education to engaging in formal critical thought, from workers demanding respect for a job well done to writers witnessing the history of their time, from electoral nonparticipation to religious worship and to teacherstudent inquiry and dialogue. A very good example of living in truth is the funeral commemoration and march on November 17, 1989, by five hundred students from Charles University to Wenceslas Square, in honor of nine who had died fighting the Fascists -- nine who refused to live the lie of an earlier totalitarianism. When the police beat those marchers on that November day, the final stage of the liberation of Czechoslovakia began.

\section{Conclusion}

Thus, Havel believes he has glimpsed in the Czechoslovakian struggle a "pretheoretical anti-politics," grounded in communities characterized by independent culture wherein individuals learned to live within the truth of their own personal hierarchy of values. It is a politics from below enabling their escape from the fate that haunted central Europeans for forty years: having to live within the lie of the regime. Havel believes only this kind of politics will generate in the future the range of pre-political gestures, signs, and movements prerequisite to a humane 
polis. It is to be a politics not of formalistic and ritualistic western democracies with their "new totalitarianism of consumption, commerce and money" (1990b, $20)$, but of a new post-democratic society.

Will it work? While there are no guarantees, Havel seems confident. "I assure you that these apparently naive words stem from a very concrete and not always easy experience with the world and, if I may say so, I know what I am talking about" (Havel 1989c, 154).

As for the specifics, Havel refuses to go into details. "This is not something," he writes, "that can be designed and introduced like a new car" (Havel $1985,52)$. He recognizes that his notions

could be developed further, but I think it would be a foolish undertaking . . . because slowly but surely the whole idea would become alienated .... The essence of such a "post-democracy" is ... that it can only develop ... as a process deriving directly from life .... It would be presumptuous to try and foresee the structured expressions of this new spirit (Havel 1985, 94).

In a much studied work published in the year of the Velvet Revolution in Czechoslovakia, American philosopher Richard Rorty explored the difficulties of overcoming authority without claiming authority (Rorty 1989). Two centuries earlier, Thomas Jefferson had struggled with how to do a revolution and establish a regime so that each generation could be free to make of the world what it wished. Václav Havel seems to think he sees a way to avoid the problem Rorty highlights and achieve the end Jefferson sought.

\section{REFERENCES}

Ash, Timothy Garton. 1991. The Magic Lantern. New York: Random House.

Felton, John. 1990. An Intellectual's Lessons. Congressional Quarterly Weekly Report. February 14: 607-609.

Gastil, Raymond G. 1990. What Kind of Democracy? The Atlantic Monthly. June: 9296.

Havel, Václav. 1985. The Power of the Powerless. In The Power of the Powerless: Citizens Against the State in Central-Eastern Europe, ed. John Keane. New York: M.E. Sharpe.

1989a. Acceptance Speech for German Peace Prize. The Independent Weekend (London). December 9: 29.

1989b. An Anatomy of Reticence. In Living in Truth: Twenty-two Essays Published on the Occasion of the Award of the Erasmus Prize to Václav Havel, ed. Jan Vladisav. London: Faber.

. 1989c. Politics and Conscience. In Living in Truth:Twenty-two Essays Published on the Occasion of the Award of the Erasmus Prize to Václav Havel, ed. Jan Vladisav. London: Faber. 
1989d. Six Asides About Culture. In Living in Truth:Twenty-two Essays Published on the Occasion of the Award of the Erasmus Prize to Václav Havel, ed. Jan Vladisav. London: Faber.

1989e. Thriller. In Living in Truth: Twenty-two Essays Published on the Occasion of the Award of the Erasmus Prize to Václav Havel, ed. Jan Vladisav. London: Faber.

. 1990a. Disturbing the Peace: A Conversation With Karel Hvizdala. New York: Knopf.

. 1990b. The Velvet Hangover. Harper's Magazine. October: 18-21.

Kohak, Erazim. 1990. What's Central to Central Europe? Harper's Magazine. June: 1720.

Lukes, Steven. 1989. Introduction. In The Power of the Powerless: Citizens Against the State in Central-Eastern Europe, ed. John Keane. New York: M.E. Sharpe.

O'Brien, Conor Cruise. 1988. Passion and Cunning: Essays on Nationalism, Terrorism, and Revolution. New York: Simon and Schuster.

Rorty, Richard. 1989. Contingency, Irony, and Solidarity. Cambridge: Cambridge University Press.

Rosen, Jay. 1990. Missing Havel's Message. World Monitor. November: 26-28.

Roskin, Michael G. 1991. The Rebirth of East Europe. New Jersey: Prentice Hall.

Rousseau, Jean-Jacques. 1954. The Social Contract, ed. Willmoore Kendall. Chicago: Henry Regnery Co.

Schama, Simon. 1989. Citizens: A Chronicle of the French Revolution. New York: Knopf. 